\title{
BRITISH MUSEUM NATURAL RADIOCARBON MEASUREMENTS XXII
}

\author{
JANET AMBERS, KEITH MATTHEWS and SHERIDAN BOWMAN \\ Research Laboratory, The British Museum, London WC1B 3DG, England
}

The following list consists of dates, obtained by liquid scintillation counting of benzene, for archaeologic samples mostly measured between June 1987 and October 1989.

Charcoal and grain samples were pretreated with $1 \mathrm{M} \mathrm{HCl}$ followed by washing in water and, where considered necessary, with dilute alkali for the removal of humic acids. Wood samples were treated either in the same way, or, where large enough, were reduced to cellulose by the action of chlorine dioxide produced in situ. All antler and bone samples were treated with cold dilute acid. The term 'collagen' is used throughout to mean the acid insoluble organic fraction produced by this treatment. Peat samples were treated with dilute acid and alkali to separate the humin and humic acid fractions, which were dated individually.

The dates were obtained by liquid scintillation counting of benzene in low-potassium glass vials, specially selected for similar backgrounds (Ambers, Leese \& Bowman 1986) in a Packard model 3255 scintillation counter or an LKB Wallac Rackbeta 1612 ("Kangeroo" version) using butyl PBD directly dissolved in benzene as a scintillator. The maximum sample size was $5.5 \mathrm{~mL}$ and smaller samples were made up to this volume with 'dead' benzene. Samples were counted for a minimum total period of 2000 minutes in trains containing at least 2 background, 2 modern and 1 known-age sample prepared from cellulose extracted from dendrochronologically dated wood supplied by Drs Pilcher and Baillie of the Belfast laboratory. There was staggered and regular replacement of these standards together with monitoring of the count rates. The result calculated from the first 40 counts for each known-age sample is published in the date list below, together with the true calendar age, and high-precision determination for wood from the same period. Each sample in the train was counted in successive 50-minute periods to achieve quasi-simultaneous counting.

Dates are expressed as suggested by Stuiver and Polach (1977) ie, in radiocarbon years relative to $\mathrm{AD} 1950$, based on the Libby half-life for ${ }^{14} \mathrm{C}$ of $5570 \mathrm{yr}$, and corrected for isotopic fractionation $\left(\delta^{13} \mathrm{C}\right.$ values are given relative to $\left.\mathrm{PDB}\right)$. We have followed the 1986 recommendations on the expression of calibrated and uncalibrated dates (Mook 1986). The modern reference standard is the NBS oxalic acid.

Errors quoted are the counting error for the sample combined with an estimate of the errors contributed by the modern and background samples. This estimate includes both counting and non-counting errors, the latter being computed from differences in the overall count rates observed among the individual backgrounds and moderns. The overall error is given as \pm 1 standard deviation $( \pm 1 \sigma)$.

Descriptions, comments and references to publications are based on information supplied by submitters. National Grid Reference is abbreviated to NGR throughout the text. 


\section{ARCHAEOLOGIC SAMPLES}

British Isles

\section{Beaker series}

Collagen from human bone samples assoc with Beaker pottery in the British Isles. Subm by A Gibson, Univ Leicester and I Kinnes, Dept Prehist and Romano-British Antiquities, British Mus.

\section{BM-2512. Chealamy}

$3630 \pm 50$

$$
\delta^{13} \mathrm{C}=-20.9 \%
$$

Collagen from human femur (ref INVMG: 1983.153 \& Bettyhill) from cist burial at Chealamy (Gourlay 1984), Sutherland, Scotland $\left(58^{\circ} 30^{\prime} \mathrm{N}, 4^{\circ} 10^{\prime} \mathrm{W}\right.$; NGR NC 724502$)$ assoc with N/NR Beaker. Coll 1983.

\section{BM-2513. Boysack Mill}

Collagen from human femur (ref CMS/3/A/21 1980-272(2)) from flat cist burial at Boysack Mill (Thoms 1978), Inverkeilor, Angus, Scotland (56 $46^{\circ} \mathrm{N}, 2^{\circ} 40^{\prime} \mathrm{W}$; NGR NO 628491), assoc with N3 Beaker. Coll 1978.

\section{BM-2514. Fodderty}

$\mathbf{3 7 7 0} \pm \mathbf{5 0}$

Collagen from human femur (ref INVMG: 1980.011.008) from flat cist burial at Fodderty, Ross and Cromarty, Scotland $\left(57^{\circ} 30^{\prime} \mathrm{N}, 4^{\circ} 30^{\prime} \mathrm{W}\right.$; NGR NH 510592) assoc with N4 Beaker. Coll 1980.

\section{BM-2515. Bractullo}

Collagen from human femur (ref CM5/6/A11 1973-800) from contracted cist burial (Boyd 1967; Coutts 1971a) at Bractullo, Angus, Scotland (56 $40^{\circ} \mathrm{N}, 2^{\circ} 50^{\prime} \mathrm{W}$; NGR NO 524473), assoc with butt end of stone axe, flint knives and scrapers, retouched flint flakes and N/NR Beaker. Coll 1967.

\section{BM-2516. Shrewton 24}

$$
\begin{array}{r}
\mathbf{3 7 5 0} \pm \mathbf{5 0} \\
\delta^{13} C=-20.5 \% 0
\end{array}
$$

Collagen from human femur (ref Field no. 5) from crouched adult male burial in pit in Barrow 24, one of group of barrows (Green \& Rollo-Smith 1984) near Shrewton, Wiltshire, England $\left(51^{\circ} 10^{\prime} \mathrm{N}, 1^{\circ} 50^{\prime} \mathrm{W}\right.$; NGR SU 095443) assoc with S4 Beaker. Coll 1958.

\section{BM-2517. Shrewton 5a}

$3560 \pm 50$

$\delta^{13} \mathrm{C}=-20.1 \%$ 。

Collagen from human femur and tibia (ref Field no. 29) from adult male burial in Pit 1, primary burial in round Barrow 5a, one of group of barrows near Shrewton (Green \& Rollo-Smith 1984), Wiltshire, England (51 $10^{\prime} \mathrm{N}, 1^{\circ} 50^{\prime} \mathrm{W}$; NGR SU 089449), assoc with N3 Beaker. Coll 1960. 
BM-2518. Handley Down

$3760 \pm 50$

$\delta^{13} C=-19.0 \%$

Collagen from human femur (ref Skeleton 10) from adult male burial in flat grave at Handley Down, near Wor Barrow (Pitt Rivers 1898 ), Sixpenny Handley, Dorset, England ( $51^{\circ} 00^{\prime} \mathrm{N}, 2^{\circ} 00^{\prime} \mathrm{W}$; NGR SU 012173) assoc with FN Beaker. Coll 1890.

\section{BM-2519. Rotherley}

$3390 \pm 50$

$\delta^{13} \mathrm{C}=-20.1 \% 0$

Collagen from human femur (Ref 1886-7) from burial at Rotherley (Pitt Rivers 1888), Wiltshire, England $\left(51^{\circ} 00^{\prime} \mathrm{N}, 2^{\circ} 00^{\prime} \mathrm{W}\right.$; NGR ST 950195) assoc with WMR Beaker. Coll 1886.

BM-2520. Radley Barrow Hills

$3630 \pm 60$

$\delta^{13} \mathrm{C}=-21.8 \%$ 。

Collagen from fragments of tibia, fibula and skull from human burial (F206) in flat grave at Radley Barrow Hills, near Abingdon, Oxfordshire, England (51 $30^{\prime} \mathrm{N}, 1^{\circ} 10^{\prime} \mathrm{W}$; NGR SU 513982) assoc with AOC Beaker. Coll 1983 and subm by Claire Halpin, Oxford Archaeol Unit.

\section{BM-2521. Smeeton Westerby}

$$
\begin{array}{r}
3440 \pm \mathbf{5 0} \\
\delta^{13} C=-20.2 \% \circ
\end{array}
$$

Collagen from human femur, tibia and pelvis (Ref A435) from burial at Smeeton Westerby (Rutland 1975), Leicestershire, England $\left(52^{\circ} 30^{\prime} \mathrm{N}, 1^{\circ} 00^{\prime} \mathrm{W}\right.$; NGR SP 671912$)$ assoc with WMR Beaker. Coll 1973.

\section{BM-2522. Risby}

$3660 \pm 50$

Collagen from human femur (Ref 1977-400) from burial in central grave under barrow at Risby (Vatcher \& Vatcher 1976), Suffolk, England (52 ${ }^{\circ} 10^{\prime} \mathrm{N}, 0^{\circ} 40^{\prime} \mathrm{W}$; NGR TL 794685) assoc with East Anglian Beaker. Coll 1964.

\section{BM-2523. Cookston Farm}

$3800 \pm 50$

$\delta^{13} \mathrm{C}=-19.2 \%$

Collagen from human femur (Ref CMJ/6/B/18 1978-2155), from flat cist burial at Cookston

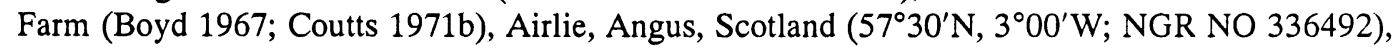
assoc with N2 Beaker and bone button. Coll 1970.

\section{BM-2524. Middle Brighty Farm}

$3730 \pm 50$

$\delta^{13} \mathrm{C}=-19.4 \%$ 。

Collagen from human femur (Ref $\mathrm{CMJ} / 5 / \mathrm{A} / 21,1973-795)$, from cist burial at Middle Brighty Farm, Tealing, Angus, Scotland $\left(56^{\circ} 40^{\prime} \mathrm{N}, 2^{\circ} 40^{\prime} \mathrm{W}\right.$; NGR NO 630510$)$ assoc with N3 Beaker. Coll 1947.

\section{BM-2525. Shrewton 5k}

$3590 \pm 50$

$\delta^{13} C=-20.2 \%$

Collagen from human femur (ref Field no. 10), from secondary burial of adult male in Pit 1 
in Barrow 5k, one of group of barrows near Shrewton (Green \& Rollo-Smith 1984), Wiltshire,

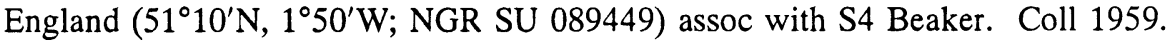

BM-2590. Achavanich

$$
\begin{array}{r}
\mathbf{3 7 0 0} \pm \mathbf{5 0} \\
\delta^{13} \mathrm{C}=-20.2 \% 0
\end{array}
$$

Collagen from female human femur from articulated burial in rock-cut grave with stone burial cist at Craig na Feich, Achavanich, Caithness, Scotland $\left(58^{\circ} 25^{\prime} \mathrm{N}, 3^{\circ} 25^{\prime} \mathrm{W}\right.$; NGR ND 178433) assoc with Beaker, ox scapula and small flints.

General Comment (JA): full details of Beaker dating program and comment will be published in Scottish Archaeol Forum, forthcoming.

England

BM-2498. Brixworth

$\mathbf{1 1 5 0} \pm \mathbf{5 0}$

$\delta^{13} \mathrm{C}=-25.1 \%$ 。

Charcoal sample, ref 898, from organic fill of pre-narthex ditch at All Saints' Church, Brixworth, Northamptonshire $\left(52^{\circ} 20^{\prime} \mathrm{N}, 0^{\circ} 55^{\prime} \mathrm{W}\right.$; NGR SP 745708$)$. Subm by D Parsons, Univ Leicester.

Comment (DP): for other dates from site, see BM-2047, -2047A, -2048, -2154, -2155 (Burleigh, Ambers \& Matthews 1984: 62, all now revised and reissued in Bowman, Ambers \& Leese 1990: 69); BM-2387, -2423 (Ambers, Matthews \& Bowman 1987: 181). Material may have been introduced into ditch fill at time of digging of foundations for west range of chambers, but must nevertheless be contemporary with, or earlier than, date of construction of first phase of church. Calibrated date range, 810-960 cal AD (Stuiver \& Pearson 1986; 1o error) implies later construction period than previously thought.

\section{Eton Wick series}

Samples from early Neolithic levels in ditch terminal (Context 018), in causewayed enclosure at Eton Wick, 1st terrace of R Thames, Berkshire (51 $30^{\prime} \mathrm{N}, 0^{\circ} 40^{\prime} \mathrm{W}$; NGR SU 950781). Coll 1985 and subm by S Ford, E Berkshire Archaeol Survey.

\section{BM-2533. Eton Wick}

Collagen from bone, Ref B, (cow; metatarsals and humerus) identified by Annie Grant, Univ Reading, from lowest level of ditch terminal.

\section{BM-2534. Eton Wick}

$4680 \pm 110$

Collagen from bone, Ref C, (cow; vertebrae, horn core and skull) identified by Annie Grant, from upper levels of primary fill, possibly result of deliberate deposition.

\section{BM-2535. Eton Wick} $4680 \pm 50$

$\delta^{13} C=-20.3 \% 0$

Collagen from bone, Ref E, (cow; tibia, mandible, phalange, scapula, tarsal, metatarsal and 
calcaneum) identified by Annie Grant, from primary fill of ditch.

General Comment (SF): samples were assoc with Abingdon and Windmill Hill styles of pottery and are broadly comparable nearest ${ }^{14} \mathrm{C}$-dated causewayed enclosure (Abingdon; BM-352, -354, -355; Barker, Burleigh \& Meeks 1971: 171).

\section{BM-2546. Runnymede}

Collagen from bone sample (Ref ERB80 A10 597) from bone refuse dumped in pit in stratified Middle Neolithic sequence, sealed by secondary gravel dump at Runnymede Bridge, Berkshire $\left(51^{\circ} 30^{\prime} \mathrm{N}, 1^{\circ} 30^{\prime} \mathrm{W}\right.$; NGR TQ 018718). Coll 1980 by R Poulton, Surrey Archaeol Unit and subm by SP Needham, Dept Prehist \& Romano-British Antiquities, British Mus.

Comment (SPN): cf BM-2550, -2551 (Ambers, Matthews \& Bowman 1989: 17, for other dates from site). Determination falls at late end of range obtained by Harwell Laboratory (unpub) for comparative Middle Neolithic assoc elsewhere on site (Areas 4, 6, 8).

\section{BM-2565. Bridgemere}

$$
\begin{array}{r}
\mathbf{4 6 3 0} \pm \mathbf{5 0} \\
\delta^{13} C=-23.4 \% \circ
\end{array}
$$

Bulked charcoal sample from Context 012 , fill of oval hearth, feature alongside bowl-shaped pit in which Early Bronze Age hoard had been accidentally discovered at Bridgemere, Cheshire, England $\left(53^{\circ} 00^{\prime} \mathrm{N}, 2^{\circ} 25^{\prime} \mathrm{W}\right.$; NGR ST 715454$)$. Coll 1986 and subm by RC Turner, Cheshire Co Council.

Comment (RT): area of $300 \mathrm{~m}^{2}$ around findspot of Arreton phase hoard was excavated revealing only three prehistoric features and few flints. Divergent dates of two major features adds to problem of why hoard was deposited at this location.

\section{Street House Wossit series}

Samples from Street House Wossit palisade enclosure, south of Street House Farm, Loftus, Cleveland $\left(54^{\circ} 30^{\prime} \mathrm{N}, 0^{\circ} 50^{\prime} \mathrm{W}\right.$; NGR NZ 739189). Coll 1986 and subm by D Jelley and B Vyner, Cleveland Co Council, Archaeol Section.

BM-2566. Street House Wossit

$$
3740 \pm 60
$$

Charcoal, Ref 24 (Quercus sp) identified by J Ambers, from large posthole in outer gully. Measured to determine date of construction of palisade. Fractionation correction estimated at $-25.0 \%$.

\section{BM-2567. Street House Wossit}

$3700 \pm 50$

$$
\delta^{13} \mathrm{C}=-24.3 \%
$$

Wood charcoal, Ref 28 (Quercus sp) identified by J Ambers, from posthole in gully break.

General Comment (BV): dates confirm construction and use of monument in beginning of Bronze Age. Main use of site (apparently ritual) was later followed by Mid-Bronze Age activity; includes deposition of at least one cremation in collared urn. 


\section{Harden Cairn series}

Samples from Early Bronze Age ring cairn on Harden Moor, NNW of Bingley, W Yorkshire $\left(53^{\circ} 50^{\prime} \mathrm{N}, 1^{\circ} 50^{\prime} \mathrm{W}\right.$; NGR SE 075386). Coll 1984 and subm by J Henderson, Research Lab for Archaeol and History of Art, Univ Oxford.

\section{BM-2572. Harden Cairn}

$3390 \pm 50$

$\delta^{13} \mathrm{C}=-24.9 \%$

Bulked charcoal, Ref 1 (Quercus sp) identified by P Franklin, Dept Forestry, Univ Oxford, from sandy layer below ring bank, possibly carbonized remains of stakes of wooden stake circle.

\section{BM-2573. Harden Cairn}

$3570 \pm 60$

Charcoal, Ref 2 (Quercus or Castanea sp) identified by P Franklin, from cremation pit cut into Bronze Age surface on interior of ring bank in NW quad, assoc with cremated bone, accessory cup base, clay toggle and chert artifacts.

\section{BM-2574. Harden Cairn}

$3530 \pm 50$

$\delta^{13} \mathrm{C}=-24.0 \%$

Charcoal, Ref 3 (Quercus sp) identified by P Franklin, from cremation pit, cut into base of ring bank in SW quad, sealed by recumbent stone, assoc with cremated bone.

\section{BM-2575. Harden Cairn}

Charcoal, Ref 4 (Quercus sp) identified by P Franklin, from cremation pit, in NW quad, sealed by recumbent stone, assoc with cremated bone.

\section{BM-2576. Harden Cairn}

Charcoal sample Ref 5 (Quercus sp) identified by P Franklin from cremation pit cut into base of bank on $\mathrm{E}$ of site, sealed by ring bank, assoc with cremated bone and pygmy cup.

General Comment (JH): BM-2572 is youngest date in series and provides terminus post quem for ring bank. Other dates provide firm Early Bronze Age attribution for cremation deposits on site and all probably fall within same early phase of activity (as indicated by stratigraphy). Measurements provide terminus post quem for stone circle which was pushed over to seal some of cremation pits. Oak is long-lived species but dates still indicate that post ring is later than cremation deposits and possibly later than stone circle.

\section{BM-2596. Petters Sports Field}

$2610 \pm 60$

$\delta^{13} \mathrm{C}=-25.5 \%$

Collagen from large bone fragments from second layer down in butt end of large ditch in Area 1, into which bronze hoard was inserted, and assoc with small group of Late Bronze Age pottery, in Late Bronze Age enclosure at Petters Sports Field, The Avenue, Egham, Surrey, England $\left(51^{\circ} 30^{\prime} \mathrm{N}, 0^{\circ} 35^{\prime} \mathrm{W}\right.$; NGR TQ 016715). Coll 1976 and subm 1988 by SP Needham, Dept Prehist and Romano-British Antiquities, British Mus. 
Comment (SPN): measurement is very close to result for charcoal from layer above (BM-1624N; BM-1620 to -1625 have been withdrawn, full details given in Bowman, Ambers \& Leese 1990: 62-65). Two layers bracket deposition of Ewart phase bronze hoard (Late Bronze Age) which is thus most likely to fall in 9th or early 8th centuries cal BC on basis of calibrated results. This accords well with expectations.

\section{West Kennet series}

Samples from outer ditch of double-palisaded enclosure in upper Kennet Valley at W Kennet, Wiltshire, England $\left(51^{\circ} 25^{\prime} \mathrm{N}, 1^{\circ} 50^{\prime} \mathrm{W}\right.$; NGR SU 111682). Coll 1987 and subm by A Whittle, Univ Wales, Cardiff.

\section{BM-2597. West Kennet}

$\mathbf{3 8 1 0} \pm \mathbf{5 0}$

$\delta^{13} \mathrm{C}=-20.8 \% 0$

Collagen from antler (red deer) Find no. 322, from Tr D, Layer 2, primary construction of outer ditch. Found rammed in deliberate chalk backfill, $90 \mathrm{~cm}$ below modern surface.

\section{BM-2602. West Kennet}

$3620 \pm 50$

$$
\delta^{13} \mathrm{C}=-20.7 \%
$$

Collagen from antler (red deer) Find no. 262, from Tr D, Layer 2, primary construction of outer ditch. Found in edge of postpipe $67 \mathrm{~cm}$ below modern surface.

General Comment (AW): dates confirm predicted late Neolithic/Early Bronze Age date of enclosure. Assoc in same trench was ripple-flaked oblique flint arrowhead. Two dates are for same archaeol context and overlap at $2 \sigma$.

\section{Kirkburn series}

Samples from Kirkburn, N Humberside, England ( $54^{\circ} 00^{\prime} \mathrm{N}, 0^{\circ} 30^{\prime} \mathrm{W}$; NGR SE 984574). Coll 1987 and subm by I Stead, Dept Prehist and Romano-British Antiquities, British Mus.

\section{BM-2619. Kirkburn}

$$
\begin{array}{r}
\mathbf{1 8 8 0} \pm \mathbf{5 0} \\
\delta^{13} \mathrm{C}=-18.1 \% \circ
\end{array}
$$

Collagen from horse metatarsal, Ref KNRB, identified by AJ Legge, Birkbeck College, Univ London, from 1 of 2 horse burials, each in shallow grave at center of small ring-ditch, both within Neolithic enclosure and close to Iron Age enclosure.

\section{BM-2620. Kirkburn}

$$
\begin{array}{r}
\mathbf{3 3 7 0} \pm \mathbf{5 0} \\
\delta^{13} \mathrm{C}=-21.2 \% 0
\end{array}
$$

Collagen from human bone from complete skeleton in grave within Neolithic enclosure and close to horse burial dated by BM-2619, above.

\section{BM-2674. Kirkburn}

$1940 \pm 50$

$\delta^{13} \mathrm{C}=-22.5 \%$ 。

Collagen from horse metatarsal, Ref KNPY, identified by AJ Legge, from second of two horse burials, first of which was dated by BM-2619, above.

General Comment (IS): BM-2620 dates secondary Bronze Age burial within Neolithic enclosure. 
Early Roman date for horse burials indicated by BM-2619 and -2674 is surprising as there is no activity of that period in immediate area.

\section{Bristol St Augustine series}

Samples from early period of Saxo-Norman cemetery assoc with church of St Augustine the Less, College Green, Bristol, England (51 $30^{\prime} \mathrm{N}, 2^{\circ} 40^{\prime} \mathrm{W}$; NGR ST 585727). Coll 1983-1984 and subm by EJ Boore, City of Bristol Museum.

\section{BM-2599. Bristol}

$\mathbf{8 9 0} \pm \mathbf{5 0}$

$\delta^{13} \mathrm{C}=-19.5 \%$

Collagen from human tibia, Ref B.82(ZX), identified by Juliet Rogers, Univ Bristol, from Burial 82, earth-cut grave with internal ledges.

BM-2600. Bristol

$$
\delta^{13} \mathrm{C}=\begin{array}{r}
\mathbf{6 9 0} \pm \mathbf{5 0} \\
-18.7 \%
\end{array}
$$

Collagen from human femur, Ref B.135 (AMD), identified by J Rogers, from Burial 135.

\section{BM-2601. Bristol}

$$
\delta^{13} \mathrm{C}=\begin{array}{r}
\mathbf{9 8 0} \pm \mathbf{5 0} \\
-18.1 \% \circ
\end{array}
$$

Collagen from human femur, Ref B.128 (ALC), identified by J Rogers, from Burial 128, in body-shaped earth-cut grave with head niche.

General Comment (EJB): ${ }^{14} \mathrm{C}$ results and grave ritual for Burials B.82 and B.128 suggest date around period of Norman Conquest for cemetery which ante-dated first stone church on site (Boore 1986: 211). Cemetery is contemporary with Late Saxon figure sculpture relief of Christ's Harrowing of Hell (Smith 1976: 101; Zarnecki 1984: 150).

\section{Ireland}

\section{Known Age series}

Cellulose extracted from dendrochronologically dated wood samples supplied by $\mathrm{M}$ Baillie and J Pilcher, Queen's Univ, Belfast, measured as check on accuracy of system.

BM-2561. Known Age 3010 BC

BM-2616. Known Age 3010 BC
$4360 \pm 50$

$$
\delta^{13} \mathrm{C}=-23.9 \%
$$

$4370 \pm 50$

$\delta^{13} \mathrm{C}=-24.4 \% 0$

Cellulose from wood sample from Balloo Cottage, dendrochronologically dated to bi-decade centered on $3010 \mathrm{BC}$.

Comment (JA \& SB): compare with result of $4345 \pm 14$ BP measured by Pearson et al (1986) for wood from same rings.

BM-2563. Known Age AD 1015

$1020 \pm 50$

$\delta^{13} C=-24.4 \%$ 。 
BM-2564. Known Age AD 1015

$1060 \pm 50$

$\delta^{13} \mathrm{C}=-23.8 \%$

Cellulose from wood sample from Toome, dendrochronologically dated to bi-decade centered on $\mathrm{AD} 1015$.

Comment (JA \& SB): compare with result of $1020 \pm 17$ BP measured by Pearson et al (1986) for wood from same rings.

Wales

\section{Early Welsh Mining}

Series of samples dated to investigate early copper mining activity in Wales. Coll 1988 and subm by PT Craddock, Research Lab, British Mus, for Early Mines Research Group.

\section{Nantyreira series}

Samples from reopening and extension of 1930 s trench cut into early mine reworked in 19th century at Nantyreira (Timberlake 1988), Hafren Forest, Plynlimon, Powys, Wales (52 $30^{\prime} \mathrm{N}$, $3^{\circ} 40^{\prime} \mathrm{W}$; NGR SN 828873).

BM-2581. Nantyreira

$$
\begin{array}{r}
3390 \pm 80 \\
\delta^{13} C=-26.3 \% 0
\end{array}
$$

Charcoal, Ref 1 , Site 1 , Context 6 , base of dump directly on edge of old trench.

BM-2583. Nantyreira

Charcoal, Ref 3/4, Site 2, Context 4.

$$
\begin{array}{r}
\mathbf{3 4 1 0} \pm \mathbf{5 0} \\
\delta^{13} C=-25.6 \%
\end{array}
$$

\section{Parys Mountain series}

Samples from apparently early mining activity at Parys Mountain (Timberlake 1988), near Amlych, Angelsey, Wales $\left(52^{\circ} 25^{\prime} \mathrm{N}, 4^{\circ} 20^{\prime} \mathrm{W}\right.$; NGR SH 444906$)$.

\section{BM-2584. Parys Mountain}

$3550 \pm 50$

Charcoal, Ref $44 / 55$, Site 3 , Context 20, base of spoil heap.

$$
\delta^{13} \mathrm{C}=-23.9 \%
$$

\section{BM-2585. Parys Mountain}

$3490 \pm 50$

$$
\delta^{13} \mathrm{C}=-25.2 \%
$$

Charcoal, Ref 29, Context 13, discrete area of burned stones and charcoal resting on clay.

\section{BM-2586. Parys Mountain}

$3500 \pm 50$

Charcoal, Ref $7 \& 3$, Site $3 \mathrm{~A}$, top of spoil heap.

$$
\delta^{13} \mathrm{C}=-25.2 \%
$$

General Comment (PTC): there are ca 20 copper mines in north and central Wales where stone mining hammers are found in considerable numbers. Some of the sites, including two reported here, were investigated by Oliver Davies in the 1930s and 1940s, and which he reported were Roman. Since then, speculation has varied from Bronze Age to 19th century AD. The Early Mines Research Group investigated two mines (directed by S Timberlake) to establish age of mines 
worked by firesetting and with stone hammers. Areas were cut through old mine tips adjacent to Davies' trenches and samples of charcoal from firesetting operations taken. Dates reported here accord well with those from hammerstone sites in Ireland, at Mt Gabriel, County Cork (O'Brien 1987), in Wales at Cwmystwyth, Dyfed (Timberlake 1987) and at Great Orme's Head, Llandudno, Gwynedd (James 1988). If dating is extrapolated to other sites with stone hammers, it suggests metal production on considerable scale in West Britain and Ireland during 2nd millennium BC.

\section{Cyprus}

\section{Kissonerga-Mosphilia series}

Samples from settlement site at Kissonerga-Mosphilia, Paphos District $\left(34^{\circ} 50^{\prime} \mathrm{N}, 32^{\circ} 25^{\prime} \mathrm{E}\right)$. Coll 1985 and 1986 and subm by EJ Peltenberg as part of Lemba Archaeol Project (cf BM-2279 from same site (Ambers, Burleigh \& Matthews 1987) now corrected to BM-2279R, $4180 \pm 130$ (Bowman, Ambers \& Leese 1990).

\section{BM-2526. Kissonerga-Mosphilia}

$$
\begin{array}{r}
4690 \pm 70 \\
\delta^{13} C=-20.4 \% 0
\end{array}
$$

Combined charcoal samples, Ref R120, R122, R123 (Prunus sp) identified by T Lawrence, Royal Botanic Gardens, Kew, from Sq 22.24.3, Unit 196, Period 3 of settlement.

\section{BM-2527. Kissonerga-Mosphilia}

Combined charcoal samples, Ref R128, R129, (Morus sp) identified by T Lawrence, from Sq 18.24.2, Unit 478, occupation level of Bldg 493, Period 4 of settlement.

\section{BM-2528. Kissonerga-Mosphilia}

Charcoal sample, Ref R151 (Pinus sp) identified by T Lawrence, from Sq 22.24.3/21.24.1, Unit 626, fill of Bldg 206, Period 3 of settlement.

\section{BM-2529. Kissonerga-Mosphilia}

Charcoal sample, Ref R152 (Morus sp) identified by T Lawrence, from Sq 22.23.1, Unit 461, collapse of roof of Bldg 3, from Period 4 of settlement.

\section{BM-2530. Kissonerga-Mosphilia}

Charcoal sample, Ref 140 (Morus sp) identified by T Lawrence, from Sq 22.23.2, Unit 384, collapse of Bldg 3, from Period 4 of settlement.

\section{BM-2568. Kissonerga-Mosphilia}

$$
\begin{array}{r}
4490 \pm \mathbf{5 0} \\
\delta^{13} C=-19.7 \%
\end{array}
$$

Charcoal sample, Ref R 179, (Pinus sp) identified by T Lawrence, from Sq 18.24.2, Unit 936, burned structure supporting Bldg 855 . 
General Comment (EJP): dates are for major prehistoric settlement, Period 3 equating with dates BM-1473 to -1476 and BM-1539, -1540 (Burleigh, Matthews \& Ambers 1982: 239) from Kissonerga-Mylouthkia, Middle Chalcolithic and Period 4 with Late Chalcolithic of Cyprus. BM-2526 and -2528 are early and may come from structural timbers of large building. BM-2527 suggests that series of discretely located structures are broadly contemporary with major exposure on site and BM-2530, that end of Chalcolithic period may be placed shortly after mid-third millennium BC. BM-2568 is relevant to Middle Chalcolithic deposit in sounding adjacent to major excavated area of site and is older than BM-2279R as expected on basis of ceramic evolution, but also older than GU-2168 (4210 $\pm 105 \mathrm{BP})$ which is from same building. Fits very few dates available for period.

\section{Ecuador}

\section{Agua Blanca series}

Samples from shallow ash-filled pits underlying large artificial terrace at site of Agua Blanca (major trade and ceremonial center), Mantabi Province $\left(0^{\circ} 30^{\prime} \mathrm{S}, 80^{\circ} 00^{\prime} \mathrm{W}\right)$. Coll 1985 and subm by Colin McEwan.

\section{BM-2538. Agua Blanca}

Wood charcoal, Ref 1, Context 12.

$$
\delta^{13} \mathrm{C}=-23.7 \%
$$

\section{BM-2539. Agua Blanca}

$650 \pm 50$

Wood charcoal, Ref 2, Context 12.

$$
\delta^{13} \mathrm{C}=-22.8 \%
$$

General Comment (CMcE): results give terminus post quem for Manteno period terrace and assoc structure. Actual date of construction of terrace and structure that represent part of last major phase of public construction at Agua Blanca is likely to be close to historically recorded Spanish contact in $\mathrm{AD} 1534$.

\section{India}
BM-2578.
Zawar
$500 \pm 50$
$\delta^{13} \mathrm{C}=-22.7 \%$

Charcoal, Ref Sample 30, Site 5, Zawar (Craddock et al 1986), Udaipur district, Rajasthan $\left(23^{\circ} 20^{\prime} \mathrm{N}, 75^{\circ} 50^{\prime} \mathrm{E}\right)$ from debris assoc with zinc smelting in small retorts. Coll 1983 and subm by PT Craddock, Res Lab, British Mus.

Comment (PTC): for other dates from site, see BM-2481 to -2488 (Ambers, Matthews \& Bowman 1989: 24). Sample was taken from main area of dumps containing small retorts, on valley bottom. Date compares well with date for isolated small retort furnace (BM-2223: Ambers, Matthews \& Burleigh 1985: 519; later corrected to BM-2223R (Bowman, Ambers \& Leese 1990: 71)) from Zawar Mala. This would seem to indicate major expansion in scale of operations in late 14th to early 15 th centuries $\mathrm{AD}$ and fits in with historical record that mines were established in 1380s. 


$$
\text { Italy }
$$

\section{Gubbio series}

Samples from three sites in Gubbio region of central Italy, dated as part of Italian prehistory series (see eg, Ambers, Burleigh \& Matthews 1987: 71-74, and Ambers, Matthews \& Bowman 1989: 26). Coll 1984 and 1988 and subm by SKF Stoddart and CAT Malone, Univ Cambridge and Gubbio Project.

\section{Monte Ingino series}

Samples from Monte Ingino, Gubbio Valley, $\mathrm{N}$ of Perugia, Umbria $\left(43^{\circ} 20^{\prime} \mathrm{N}, 12^{\circ} 40^{\prime} \mathrm{E}\right)$.

BM-2499. Monte Ingino

$3090 \pm 70$

Charcoal, Ref MI 84 126, from early phase in Bronze Age midden.

$$
\delta^{13} \mathrm{C}=-22.8 \%
$$

BM-2500. Monte Ingino

$2960 \pm 50$

$\delta^{13} \mathrm{C}=-24.1 \%$

Charcoal sample, Ref MI 84 127, from major depositional phase in Bronze Age midden and stratigraphic equivalent to BM-2501 and -2502. Sealed under leveled Medieval fortification.

BM-2501. Monte Ingino

$2920 \pm 50$

$\delta^{13} \mathrm{C}=-23.4 \% 0$

Charcoal sample, Ref MI 84 50, from major depositional phase in Bronze Age midden and stratigraphic equivalent to BM-2500 and -2502. Sealed under leveled Medieval fortifications.

\section{BM-2502. Monte Ingino}

$\mathbf{2 9 3 0} \pm \mathbf{5 0}$

$\delta^{13} \mathrm{C}=-18.6 \%$

Collagen from bone, Ref MI 84 50, from major depositional phase in Bronze Age midden and stratigraphic equivalent to BM-2500 and -2501. Sealed under leveled Medieval fortifications.

General Comment (SKFS): BM-2499 corresponds with expected date for transition from Subapennine to Protovillanovan phase of Late Bronze Age of central Italy. BM-2500, -2501 and -2502 correspond with expected date for Early Protovillanovan phase of Late Bronze Age of central Italy.

\section{Monte Ansciano series}

Charcoal from two sites on Monte Ansciano, Gubbio Valley, $\mathrm{N}$ of Perugia, Umbria $\left(43^{\circ} 20^{\prime} \mathrm{N}\right.$, $\left.12^{\circ} 40^{\prime} \mathrm{E}\right)$.

BM-2503. Monte Ansciano Alto

$280 \pm 50$

$\delta^{13} \mathrm{C}=-23.4 \%$ BC.

Charcoal, Ref MA 84 25, from dark layer overlying burial cut into ritual platform of ca 600

BM-2504. Monte Ansciano Basso

$2520 \pm 80$

$\delta^{13} \mathrm{C}=-22.5 \% 0$

Charcoal from compact burned basal layer of floor of Iron Age hut, sealed under colluvial 
sediment on lower slopes of Monte Ansciano, near church of San Agontino.

BM-2591. Monte Ansciano Alto

$$
\begin{array}{r}
2680 \pm 50 \\
\delta^{13} C=-20.6 \% \circ
\end{array}
$$

Collagen from bone fragments, Ref 227-1, from old land surface sealed by Late Bronze Age drystone wall.

BM-2592. Monte Ansciano Alto

$$
2870 \pm 90
$$

Charcoal, Ref 204-1, from Bronze Age levels at base of layer 204, land surface sealed by midden. $\delta^{13} \mathrm{C}$ estimated at $-25.0 \%$.

\section{BM-2593. Monte Ansciano Alto}

$$
\begin{array}{r}
\mathbf{2 5 8 0} \pm \mathbf{5 0} \\
\delta^{13} \mathrm{C}=-25.3 \% 0
\end{array}
$$

Collagen from mixed deposit of bone fragments, Ref 204-2, from similar but slightly higher level to BM-2592, above.

\section{BM-2594. Monte Ansciano Alto}

$2610 \pm 50$

$\delta^{13} \mathrm{C}=-22.2 \%$

Collagen from mixed deposit of bone fragments, Ref 402-1 (sheep, pig and cow) identified by G Clark, from Late Bronze Age midden, sealed by dry stone block platform of Archaic period.

General Comment (SKFS): BM-2591, -2593 and -2594 for animal bone are acceptable on typological grounds of assoc artifacts, and form tight group. BM-2592 for charcoal appears slightly earlier. BM-2503 corresponds to very plausible date for sealing deposit of Medieval burials. BM-2504 corresponds to expected date of artifactual material from hut floor.

\section{Peru}

Samples measured as part of investigation of archaeol remains in Cusichaca Valley by A Kendall, Dir Cusichaca Archaeol Project.

\section{Huillca Raccay series}

Samples from burials cut into early Horizon deposits under Inca period promontory fort site at Chuncuchua, Huillca Raccay, Dept Cuzco $\left(13^{\circ} 10^{\prime} \mathrm{S}, 72^{\circ} 25^{\prime} \mathrm{W}\right)$.

BM-2569. Huillca Raccay $2290 \pm 50$

$$
\delta^{13} \mathrm{C}=-13.5 \%
$$
1985.

Collagen from femur, Ref Q211-1895-4, from securely stratified human skeleton burial. Coll

\section{BM-2570. Huillca Raccay}

$$
\begin{array}{r}
2480 \pm \mathbf{5 0} \\
\delta^{13} C=-13.2 \% 0
\end{array}
$$

Collagen from femur, Ref Q211-6057-12, from human burial in similar stratigraphic position to that dated by BM-2569, above. Coll 1981.

General Comment (JA): results earlier than expected. 


\section{BM-2571. Patallacta}

Collagen from human bone, Ref Q1-513-4, from burial in Late Prehispanic rock crevice tomb on the hillside behind Patallacta, Cusichaca Valley $\left(13^{\circ} 10^{\prime} \mathrm{S}, 72^{\circ} 25^{\prime} \mathrm{W}\right)$. Coll 1983.

Comment (JA): result as expected.

\section{Spain}

\section{Early Metallurgy in SE Spain}

Samples from Copper and Bronze Age sites in SE Spain, assoc with development of metal-working, subm by A Arribas, Univ Palma and F Molina, Univ Granada (for other results for same area, see Ambers, Matthews \& Bowman 1987: 192).

\section{Los Millares series}

Samples from Early Copper Age, "Los Millares" culture, occupation site with evidence of copper working at Los Millares, Santa Fe, Almeria $\left(37^{\circ} 00^{\prime} \mathrm{N}, 2^{\circ} 30^{\prime} \mathrm{W}\right)$. Coll 1983.

\section{BM-2536. Los Millares}

Charcoal, Ref LM-54015, from habitation level inside tower ("Fortin no. 1").

\section{BM-2537. Los Millares}

Charcoal, Ref LM-52031, from habitation level inside tower ("Fortin no. 1").

General Comment (FM): BM-2536 relates to late occupation of Fortin 1. Date is slightly earlier than expected but is acceptable for context. BM-2537 is also early for context but agrees with other date for Los Millares (BM-2345: Ambers, Matthews \& Bowman 1987: 192). Expected date was based on supposition that Fort was abandoned immediately before beginning of Beaker phase in region, because of lack of Beaker ceramics at site, but this may be due, instead, to difference in site function.

BM-2540.

El Malagon

$3900 \pm 50$

$\delta^{13} C=-23.9 \%$

Charcoal, Ref CB-11044, from habitation level in Early Copper Age, "Los Millares" culture, occupation site with evidence of metal-working at El Malagon, Cullar Baza, Granada $\left(37^{\circ} 30^{\prime} \mathrm{N}\right.$, $\left.2^{\circ} 25^{\prime} \mathrm{W}\right)$. Coll 1983.

Comment (FM): date agrees with other dates for site (BM-2347, -2348: Ambers, Matthews \& Bowman 1987: 192) and relates to period immediately before first Maritime Beaker pottery appears.

BM-2541. Castellon Alto

Charcoal, Ref G.CA-2417, from hut in Middle Bronze Age, "Argar Pleno" culture, site at 
Castellon Alto, Galera, Granada $\left(37^{\circ} 45^{\prime} \mathrm{N}, 2^{\circ} 30^{\prime} \mathrm{W}\right)$. Coll 1983.

Comment (FM): result is slightly earlier than expected. Date must correspond with first occupation at site.

\section{BM-2542. Cuestra del Negro}

$3180 \pm 50$

$\delta^{13} \mathrm{C}=-21.6 \%$

Charcoal, Ref P-5520, from hut in Late Bronze Age, "Cogotas I" culture, site at Cuestra del Negro, Purullena, Granada $\left(37^{\circ} 20^{\prime} \mathrm{N}, 3^{\circ} 15^{\prime} \mathrm{W}\right)$. Coll 1971.

Comment (FM): result agrees with expectations.

\section{BM-2543. Terrera del Reloj}

Charcoal, Ref DG-1333, from hut in Middle Bronze Age, "Argar Pleno" culture, site at Terrera

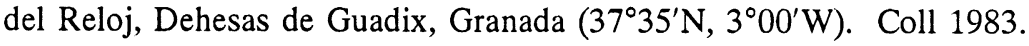

Comment (FM): result agrees well with other date for site (BM-2354: Ambers, Matthews \& Bowman 1987: 192).

\section{Moncin series}

Samples from multi-period site at Moncin, Borja, Zaragoza $\left(41^{\circ} 50^{\prime} \mathrm{N}, 1^{\circ} 30^{\prime} \mathrm{W}\right)$. Coll and subm by RJ Harrison, Dept Classics and Archaeol, Univ Bristol.

\section{BM-2606. Moncin}

$3050 \pm 50$

$$
\delta^{13} \mathrm{C}=-25.7 \%
$$

Charcoal, Ref Sample 22, Sq VIII, layer 2a from fireplace inside stone house (F63), part of last occupation of site, assoc with pottery and bronze tools of Final Bronze Age.

\section{BM-2607. Moncin}

$$
\begin{array}{r}
3300 \pm \mathbf{5 0} \\
\delta^{13} C=-24.0 \% 0
\end{array}
$$

Charcoal, ref Sample 104, (Quercus sp), Sq X, Pit F107, rubbish pit filled with butchery refuse, including horse, deer and cattle bones, part of last occupation of site before abandonment.

\section{BM-2608. Moncin}

$$
\begin{array}{r}
\mathbf{3 0 8 0} \pm \mathbf{5 0} \\
\delta^{13} C=-22.9 \%
\end{array}
$$

Charcoal, Ref 1, from fill of Pit F2, cutting earlier midden deposit. Repeat measurement from fresh material of BM-1924 which was affected by BM error (Tite et al 1988). (Cf BM-1924, 2960 \pm 40 and revised result BM-1924R, $3210 \pm 100$ : Bowman, Ambers \& Leese 1990: 76.) For mixed charcoal with inherent sample time-width, repeat samples are not true replicates.

\section{BM-2609. Moncin}

$$
\begin{array}{r}
3150 \pm 50 \\
\delta^{13} C=-26.2
\end{array}
$$

Charcoal, Ref 3, from fill of large pit, F3. Repeat measurement from fresh material of BM-1926, which was affected by BM error (Tite et al 1988). (Cf BM-1925, $3020 \pm 45$ and revised result BM-1925R, $3290 \pm 100$; Bowman, Ambers \& Leese 1990: 76.) For mixed charcoal with inherent sample time-width, repeat samples are not true replicates. 
General Comment (RJH): samples were selected to ascertain more precisely date of Bronze Age expansion phase at Moncin, linked to construction of 40+ silos in Phase IIB of site (BM-2608 and -2609), and to date site's final occupation in Phase IIA (BM-2606 and -2607). Sample BM-2607 seems too old, and may include charcoal derived from earlier periods.

\section{Sri Lanka}

\section{Anuradhapura series}

Samples from multi-period citadel at Anuradhapura, ancient capital of Sri Lanka, North Central Province $\left(8^{\circ} 20^{\prime} \mathrm{N}, 80^{\circ} 30^{\prime} \mathrm{E}\right)$. Coll 1985 and subm by SU Deraniyagala, Dept Archaeol, Colombo.

\section{BM-2505. Anuradhapura}

$2130 \pm 50$

$\delta^{13} \mathrm{C}=-23.3 \%$

Charcoal, Ref AG-85 6, from Early Historic period deposits assoc with first appearance of Brahmi script and Rouletted Ware.

\section{BM-2506. Anuradhapura}

$2170 \pm 50$

$\delta^{13} \mathrm{C}=-23.3 \%$ Ware.

Charcoal, Ref AG-85 7, from Late Protohistoric period, assoc with Northern Black Polished

\section{BM-2507. Anuradhapura}

$\mathbf{2 2 5 0} \pm \mathbf{5 0}$

$\delta^{13} \mathrm{C}=-25.9 \%$

Charcoal, Ref AG-85 8, from transition between Early and Late Protohistoric period with ceramics of both periods.

BM-2508. Anuradhapura

$2520 \pm 50$

$\delta^{13} \mathrm{C}=-23.3 \%$

Charcoal, Ref AG-85 10, from Early Protohistoric period deposits, assoc with typical ceramic assemblage.

\section{Mantai series}

Samples from occupation site at Mantai, on NW coast, $6.1 \mathrm{~km}$ SE of Mannar $\left(9^{\circ} 00^{\prime} \mathrm{N}\right.$, $\left.80^{\circ} 00^{\prime} \mathrm{E}\right)$. Coll 1984 and subm by A Graham, for J Carswell and M Prickett, Mantai project.

\section{BM-2587. Mantai}

$\mathbf{1 7 0 0} \pm \mathbf{5 0}$

Charcoal, Ref 5 MA84 G 260, from lens sealed in fill of one of series of pits used for ash/rubbish disposal.

BM-2588. Mantai

$1690 \pm 50$

Charcoal, Ref 8 MA84 G 150, from hearth assoc with two in-situ pot bases. Fractionation correction estimated at $-25.00 \%$. 
BM-2589. Mantai

$1810 \pm 50$

Charcoal, Ref 7 MA84 H 59 Post 2, from one of row of timber uprights. Fractionation correction estimated at $-25.00 \%$.

General Comment (AG): dates confirm existence of early period of occupation on site, being base of excavated sequence in central part of mound, ante-dating main development of site as port in 8th to 10 th centuries $\mathrm{AD}$.

\section{REFERENCES}

Ambers, J, Burleigh, R and Matthews, K 1987 British Museum natural radiocarbon measurements XIX. Radiocarbon 29(1): 61-77.

Ambers, J, Leese, $\mathrm{M}$ and Bowman, S 1986 Detection of bias in the background of vials used for scintillation counting. In Stuiver, $\mathrm{M}$ and $\mathrm{Kra}$, RS, eds, Internatl ${ }^{14} \mathrm{C}$ conf, 12th, Proc. Radiocarbon 28(2A): 586-591.

Ambers, J, Matthews, K and Bowman, S 1987 British Museum natural radiocarbon measurements XX. Radiocarbon 29(2): 177-196.

1989 British Museum natural radiocarbon measurements XXI. Radiocarbon 31(1): 15-32.

Ambers, J, Matthews, K and Burleigh, R 1985 British Museum natural radiocarbon measurements XVIII. Radiocarbon 27(3): 508-524.

Barker, H, Burleigh, R and Meeks, N 1971 British Museum natural radiocarbon measurements VII. Radiocarbon 13(2): 157-188.

Boore, EJ 1986 The church of St Augustine the Less, Bristol: An interim statement. Bristol Gloucestershire Archaeol Soc Trans 104: 211-214.

Bowman, SGE, Ambers, J and Leese, MN 1990 Re-evaluation of British Museum radiocarbon dates issued between 1980 and 1984. Radiocarbon 32(1): 59-80.

Boyd, JD 1967 Discovery and excavation in Scotland: Council for British Archaeology, Scottish Group, Edinburgh.

Burleigh, R, Ambers, J and Matthews, K 1984 British Museum natural radiocarbon measurements XVII. Radiocarbon 26(1): 59-74.

Burleigh, R, Matthews, K and Ambers, J 1982 British Museum natural radiocarbon measurements XIV. Radiocarbon 24(3): 229-261.

Coutts, H 1971a Tayside before history. Dundee Museum rept 77, Dundee, Scotland. 1971b Tayside before history. Dundee Museum rept 82, Dundee, Scotland.

Craddock, PT, Freestone, IC, Gurjar, LK, Hegde, KTM and Sonawane, VH, 1986 Early zinc production in India. Mining Magazine, Jan: 45-52.

Gourlay, RB 1984 A short cist Beaker inhumation from Chealamy, Strathnaver, Sutherland. Soc of Antiquaries of Scotland Proc 114: 567-571.

Green, C and Rollo-Smith, S 1984 The excavation of eighteen round barrows near Shrewton, Wiltshire. Prehist Soc Proc 50: 255-318.

James, D 1988 Prehistoric mining on the Great Orme's Head. In Ellis Jones, J, ed, Bangor conference on Ancient Mining and Metallurgy, Acta: 115-121. Univ Bangor, Bangor, Wales.

Mook, WG 1986 Business meeting: Recommendations/resolutions adopted by the Twelfth International Radiocarbon Conference. In Stuiver, $\mathrm{M}$ and $\mathrm{Kra}$, RS, eds, Internatl ${ }^{14} \mathrm{C}$ conf, 12th, Proc. Radiocarbon 28(2A): 799.

O'Brien, WF 1987 The dating of the Mt Gabriel type copper mines of West Cork. Cork Hist and Archaeol Soc, Jour 92: 50-70.

Pearson, GW, Pilcher, JR, Baillie, MGL, Corbett, DM and Qua, F 1986 High-precision radiocarbon measurements of Irish oaks to show the natural radiocarbon variations from AD 1840-5210 BC. In Stuiver, $\mathrm{M}$ and $\mathrm{Kra}$, RS, eds, Internatl ${ }^{14} \mathrm{C}$ conf, 12th, Proc. Radiocarbon, 28(2B): 911-934.

Pearson, GW and Stuiver, M 1986 High-precision calibration of the radiocarbon time-scale, 500-2500 BC, in Stuiver, M and $\mathrm{Kra}$, RS,eds, Internatl ${ }^{14} \mathrm{C}$ conf, 12th, Proc. Radiocarbon 28(2B): 839-862.

Pitt Rivers, A 1888 Excavations on Cranborne Chase, vol 2. London, Privately printed. 1898 Excavations on Cranborne Chase, vol 4. London, Privately printed.

Rutland, RA 1975 A Beaker burial at Smeeton Westerby, Leicestershire. Leicester Archaeol and Hist Soc Trans 50: 46-48.

Smith, MQ 1976 The harrowing of Hell relief in Bristol Cathedral. Bristol Gloucestershire Archaeol Soc Trans 94: 101-106.

Stuiver, M and Pearson, GW 1986 High-precision calibration of the radiocarbon time-scale, AD 1950-500 BC. In Stuiver, $\mathrm{M}$ and $\mathrm{Kra}, \mathrm{RS}$, eds, Internatl ${ }^{14} \mathrm{C}$ conf, 12th, Proc. Radiocarbon 28(2B): 805-838.

Stuiver, $\mathrm{M}$ and Polach, H 1977 Discussion: Reporting of ${ }^{14} \mathrm{C}$ data. Radiocarbon 19(3): 355-363. 
Thoms, LM 1978 Discovery and excavation in Scotland: 31. Council for British Archaeol, Scottish Group, Edinburgh. 1988 Excavations at Parys Mountain and Nantyreira. Archaeology in Wales 28: 11-18.

Timberlake, S 1987 An archaeological investigation of early mineralogy on Copa Hill, Cwmystwyth. Archaeology in Wales, 27: 18-20.

Tite, MS, Bowman, SGE, Ambers, JC and Matthews, KJ 1988 Preliminary statement on an error in British Museum radiocarbon dates (BM-1700 to BM-2315). Radiocarbon 30(1): 132.

Vatcher, F de M and Vatcher, HL 1976 The excavation of a round barrow near Poor's Heath. Prehist Soc Proc 42: 263-292.

Zarnecki, G 1984 Sculpture. In Zarnecki, G, Holt, J and Holland, T, eds, English Romanesque art 1066-1200. Arts Council of Great Britain, London. 